\title{
THE VIRUS, THE DISEASE AND THE INEQUALITY
}

\author{
Luciana R. F. C. Travassos \\ Renata M. P. Moreira \\ Rayssa Saidel Cortez
}

\footnotetext{
${ }^{I}$ Professor at Federal University of $A B C$, Bachelor in Territorial Planning and Territorial Planning and Management Graduate Program

São Bernardo do Campo/SP - Brasil

${ }^{\text {II }}$ Professor at Federal University of $A B C$, Environmental and Urban Engineering.

Santo André/SP - Brasil

III PhD canditate at Federal University of $A B C$, Territorial Planning and Management Graduate Program.

São Bernardo do Campo/SP - Brasil
}

\begin{abstract}
The advance of the COVID-19 pandemic expresses multiple territorial dimensions. The following analysis, about the data released on notified cases and deaths, allow us to raise interpretations that relate the evolution of the pandemic with the inequalities already present in the São Paulo urban space and with the different existing conditions to adhere to isolation. This article presents reviews that dialogues with the perspective of environmental justice, discussing some impacts of territorial inequalities on the life and death of São Paulo residents, such as the distribution of urban characteristics, work, comorbidities, access to health equipment, and race, that maintains a center periphery pattern. As it is an observation of an ongoing case, it is an exploratory study, with open hypotheses.
\end{abstract}

Keywords: Inequalities; periphery; COVID-19; environmental justice; São Paulo - Brazil.

São Paulo. Vol. 23, 2020

Debating ideas

The COVID-19 epoch: Interdisciplinary research towards a new just and sustainable ethics

DOI: http://dx.doi.org/10.1590/1809-4422asoc20200111vu2020L3ID 


\section{Introduction}

The outbreak of the COVID-19 pandemic in Brazil reveals a series of specific conditions. An important part of local conditions, if not totally, is related to the extreme structural inequality of Brazilian society, both in spatial terms, in various scales, and in demographic terms. There is a possibility that the spread of the new coronavirus, the SARS-CoV 2, and its disease COVID-19, due to specific characteristics, has an important and specific territorial basis, including physical and social aspects, which is defining its history in our country.

Although the observation of its trajectory in other countries has been essential to outline emergency actions to deal with the outbreak, some Brazil's environmental liabilities increase the risks to which part of the population is exposed to the crisis and poses new challenges to action. Thus, despite a first perception of the democratic spread of the virus, especially related to its entry by the highest social classes in each country, it soon appeared that both the virus and the disease overlap with other territorial inequalities. This exposes the environmental injustice all over the cities and in São Paulo, specifically, and reinforces the need to center the inequalities in the debate on planning and public policies.

The methodology collates the spatialization of census data on territorial and working conditions with data on infection and death by COVID-19 in São Paulo, through institutional communications from the City Hall. It also uses data produced through its own research on isolation. This paper explores the territorial dimensions that contribute to the uneven spread of the virus and the unequal impact of the disease, with the hypothesis that the metropolitan peripheries and precarious areas present a sum of these conditions and, therefore, risks. Finally, the territorial analysis focuses specifically on the Municipality of São Paulo, the epicenter of the crisis in Brazil.

\section{Dispersion and uneven impacts}

The observation SARS-CoV 2's outbreak leads to conclude that its contagion pattern follows global socioeconomic flows. These movements obey the worldwide connections, the virus arrives in countries through its more globalized cities and, from there, expands over nation's regional networks, mostly concentrating in one or two regions of each country (CONNOLLY et al., 2020; WOLF, 2016). The ways it works on territorial connections are reproduced in the individual scale, thus, those most connected to global and national networks are responsible for its initial dissemination.

From the arrival of the virus to the recognition of the disease and the first public actions, the followings should be rooted in the territory, mainly to its inequalities, resultant of the capitalism structure and its territorialization in periphery countries (ARMITAGE; NELLUMS, 2020; AHMED et al., 2020). The main actions to contain the pandemic face several obstacles. First, the only possible action to flatten the contagion curve, so far, is the self-isolation, quarantine and lockdown, leading to an expressive decrease in commuting. Second, the indication to avoid infection is the frequent cleaning of spaces 
and people (BATISTA; FERNANDES, 2020). Therefore, emerges two dimensions of inequality to influence the virus spread: the conditions of the home and the neighborhoods and the social division of labor.

In Brazilian big cities, peripheries and precarious areas have much higher population density, when compared with formal areas, also there is expressive home congestion, the presence of many people in a few rooms and the absence or deficiency of urban infrastructure, as pointed by environmental justice's studies (ACSELRAD, 2001; TRAVASSOS et al., 2020). Though the density cannot simply explain the spread of the virus (TORRES; LINKE, 2020), here, its morphology is generally characterized by precariousness (Figures 1 and 2).

While São Paulo City's density average is 78.68 inhabitants/ha (IBGE, 2015), in slums it rises to 548.52 inhabitants/ha (SMDU / DEINFO, 2015). In large slums, such as Paraisópolis, there are extensive areas where density exceeds 800 inhabitants/ha. Situations of high density appear even in smaller communities, as seen in, for example, 12 perimeter slums in Brasilândia, where density exceeds 600 inhabitants/ha. Furthermore, among the high-density slum sectors, there is a considerable incidence of household congestion: between 5 and $24 \%$ of houses (autoral work on spatial data from the IBGE census sectors, 2010, and the perimeter of slums, DEINFO, 2015).

\section{Figures 1 and 2 - Aclimação neighbourhood, with densities from 70 to 360 inhabitants per hectare (left); Paraisópolis Slum, with den- sities from 370 to 970 inhabitants per hectare (right)}
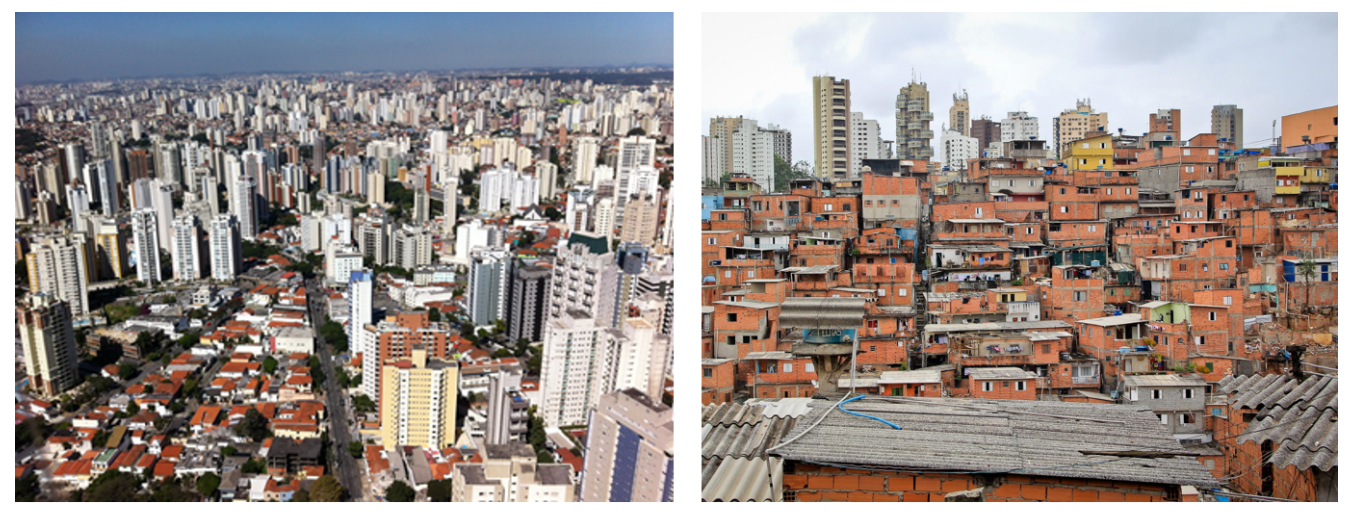

Photo: Travassos, 2013 (left); Vilar, 2014 (right).

Still analysing Brasilândia, an important part of the Census sections that intercept slums have precarious infrastructure (24.7\%), i.e., there are more than 2,200 households in the district that live with open sewage. This data can be used as a proxy for the deficiency of other infrastructure networks, as well as emphasize the increased risk for these households, due to the possibility of oral-fecal spread of the virus through sewers, pointed out in some preliminary studies (HELLER et al., 2020; autoral work on spatial data from IBGE Census sections, 2010 and the perimeter of slums DEINFO, 2015). 
The discussion above shows the difficulties of practicing isolation and adopting barriers against the contact with the virus, individually and at home. However, this population at high risk under territorial conditions is one that depends highly on commuting to work once they are in the lower income classes and have less conditions to keep savings - as salaried or informal workers. Also, they have jobs with higher levels of manual activities, which cannot be done at a distance, cannot be paralyzed and/or are essential for family's income and daily life.

The map below uses data from the 2010 Demographic Census (IBGE, 2010) ${ }^{1}$. It shows significant territorial differences in the technical composition of productive activities$^{2}$. The central areas concentrate homes of those inhabitants whose works are more related to intellectual activities, while the peripheries highly concentrate those whose works are more related to manual activities. When comparing these data with the results of the survey "Quarantine in the Neighborhood" (MOREIRA et al., 2020), it explains the impossibility of self-isolation of workers who live on the peripheries, with a significant difference in the perception of reduced flow of people between the center and this areas, as shows the figure 3 .

Regarding the disease, the dimensions that expose territorial inequalities are different, especially the presence of comorbidities and access to health, and are worsening the COVID-19 cases and deaths. There are two prevalent comorbidities that conducts to COVID-19 deaths: hypertension and diabetes, chronic diseases that are intensified by inequality.

In a study about these diseases among different class groups, Stringhini et al. (2017) concluded that poverty and inequality are the major factors of morbidity and early death worldwide. The authors observed how individual socio-occupational categories influence the relationship between the level of physical activity, alcohol and tobacco consumption and the presence of these comorbidities (STRINGHINI et al., 2017).

In Brazil, some studies relate demographic characteristics to the incidence of chronic diseases. Barros et al. (2011) found a great correlation between diseases such as hypertension, chronic renal failure, arthritis/rheumatism, tuberculosis and cirrhosis, and an increase in diabetes, and the population with less education and more dependent on the Unified Health System (Sistema Único de Saúde, SUS). In a specific study about hypertension and diabetes, Francisco et al. (2018) also found correlations between the prevalence of these diseases in the black and less educated population, which may be the result of "lack of access to social opportunities throughout life, increasing the vulnerability of this subgroup to unfavorable outcomes in old age" (FRANCISCO et al., 2018, p. 3836, our translation). Finally, focusing the municipality of São Paulo, Selem (2012) points out these relationships with the incidence of hypertension, linking them to dietary patterns.

1- This is the last data available. The next collect of Demographic Census, in 2020, was planned but it's been suspended.

2- The research considered the occupations of the Classification of Occupations for Household Surveys - COD. In the category with highly intellectual activities are directors, specialists, professionals, surpervisors, among others; while in the category of highly manual activities are personal service workers, salespeople, workers, among others. 
Figure 3 - Percentage of workers with high levels of manual and intellectual activities by district of residence

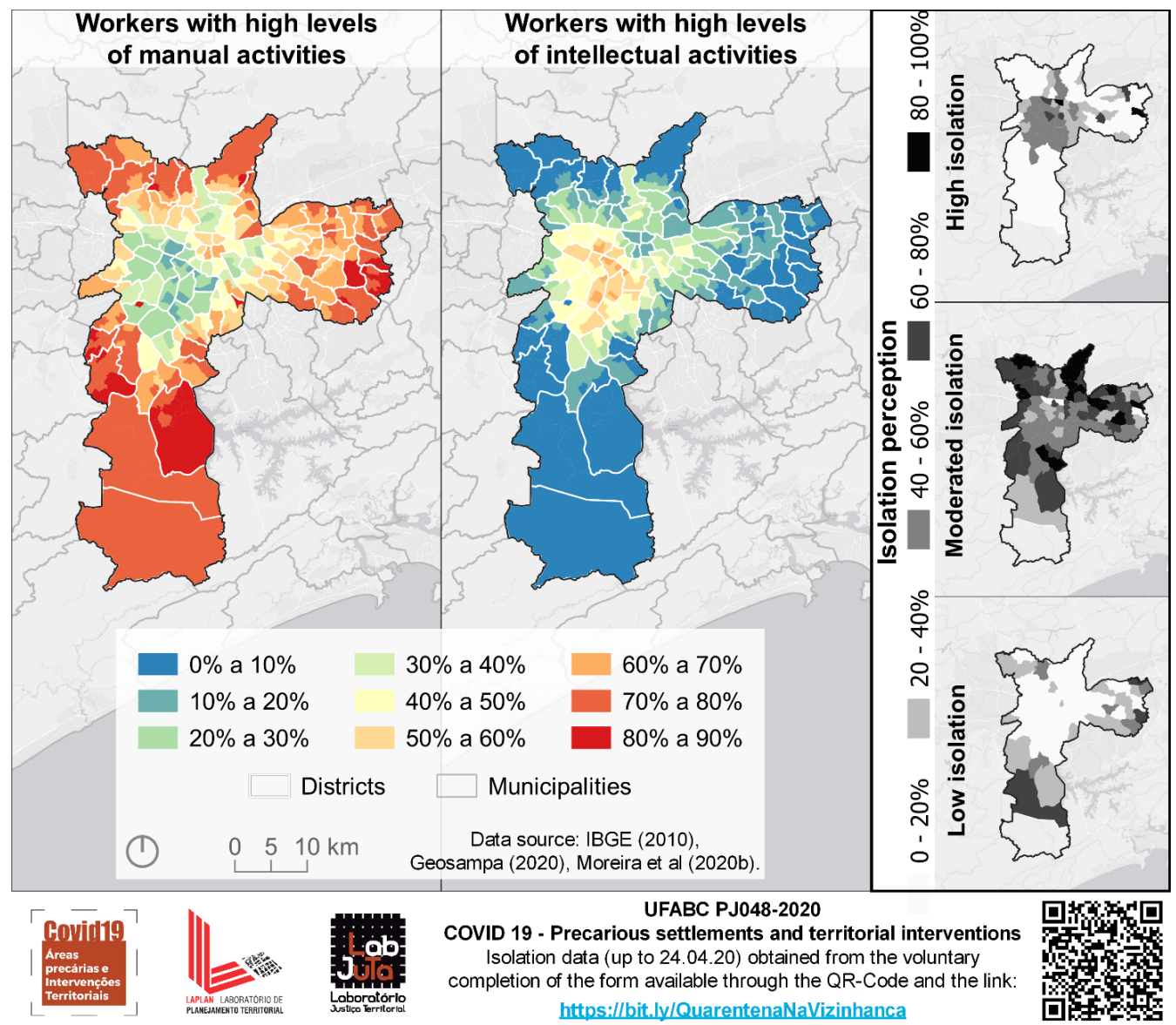

Sources: IBGE, 2010; Geosampa, 2020.

The Health Atlas of the City of São Paulo (SÃO PAULO, SMS, VIA PÚBLICA, 2012) indicates a significant concentration of deaths caused by cardiovascular diseases and diabetes in the peripheries of the municipality. Observing its map allow us to say that the difference varies up to four times for cardiovascular diseases (26.5 per thousand inhabitants in Moema and more than 100 in Brasilândia and Cidade Tiradentes) and three times for diabetes (from 12 deaths per 100 thousand inhabitants in the central districts to more than 31 in many peripheral districts).

Unequal access to health care, during life - as pointed out in the studies above and the pandemic, can also explain the relations between inequalities and comorbidities, aggravated in COVID-19 crisis. In Brazil, Noronha et al. (2020) had simulated several scenarios with SARS-CoV 2 infection rates over $1 \%$ of the population and found a great deficiency on the number of general hospital beds and ICU beds. The private ICU beds 
would have great relevance to the population attendance, in the municipality of São Paulo, e. g., considering the scenario of $1 \%$ infected in six months - an optimistic one, according to the authors -, if only the SUS beds were used, the system would exceed its capacity by $40 \%$ but the index could be reduced to $4.5 \%$, using private network beds (NORONHA et al., 2020). For register, in a bulletin of May 9 (SÃO PAULO, 2020d), the occupancy rate of the municipality ICU public beds was $89,6 \%$. It is important to emphasize that the distribution of the medium and high complexity attendances is given by micro and macro health regions network, therefore, the intra-urban concentration of beds is not causally linked to territorial inequalities. On the other hand, the availability of public beds compared to private ones is considerable, since the differences in demand between SUS and private beds also show an uneven center-periphery pattern. For example, while the demand for SUS by residents of Jardim Paulista, Itaim Bibi or Moema is, at most, $42 \%$, in poorer districts, such as Cidade Tiradentes, Guaianazes and Jardim Ângela, it exceeds 88\% (SÃO PAULO, SMS, VIA PÚBLICA, 2012).

Even briefly, it is fundamental to remember that environmental injustice has been expressed by the racial segregation bias also in the COVID-19 deaths, as a new face of environmental racism. Activists and social movements have publicly denounced both the growing infection between the black and poor population, and their higher difficulty in accessing appropriate treatment. According to the Agência Pública de Notícias, in Brazil, the infection and registered deaths of black people increased five times in April, while for white people, three times. It is yet not possible to make a complete analysis about the impacts of this inequality key, but, considering the environmental injustices in the metropolis of São Paulo, the correlation between spatial and social consequences is undeniable.

In addition to all the obstacles addressed, time is an extremely important factor when taking measures, preventive and impact mitigation, to face the COVID-19 pandemic. Both actions of risk communication - as a way to disseminate information on prevention - and the distribution of emergency hospital facilities (field hospitals) were not foreseen with the needed advance to prioritize the service so the most vulnerable population could avoid the virus and the aggravation of the disease.

\section{Death as a result}

The first data on deaths from COVID-19 in São Paulo City confirms the inequalities pointed out above. Since the beginning of the pandemic, the municipality has published daily bulletins with general numbers and more complete ones, periodically. They are the main references in public information.

While Epidemiological Bulletin 1 (31st March/2020, 639 accumulated cases in total) (SÃO PAULO, 2020a) showed a greater number of cases in the western and south richest areas (Butantã, Lapa, Pinheiros, Vila Mariana, Moema, Jabaquara), the second Bulletin (17th April/2020, total of 10,432 cases and 1,826 deaths until 16th/April) showed a different reality: the districts with the highest number of cases were Itaquera, Sapopemba, 
Jabaquara and Jardim Ângela, precarious and peripheral áreas.

In the accumulated death map between weeks 9 to 16, the most affected district was Brasilândia, followed by Sapopemba, São Mateus and Cidade Tiradentes (SÃO PAULO, 2020b). The maps of accumulated deaths, per week, presented in the Epidemiological Bulletin 2, reveal that the place of residence of the first reported deaths were peripheral neighborhoods: Jardim Helena (far east) and Santo Amaro, in weeks 9 to 11. In the next week, deaths were quite distributed throughout the city, but after epidemiological week 13 (March 22 to 28), the peripheral districts became to concentrate deaths, with a notable concentration in the districts of Brasilândia and Itaquera (SÃO PAULO, 2020c).

The Epidemiological Bulletin 3 (30th April of 2020, total of 11,025 confirmed cases by 23th April and 2,361 deaths by 21th April) shows that districts with the highest number of deaths were Brasilândia, Sapopemba and São Mateus (SÃO PAULO, 2020c). The new weekly analysis, starting from week 11, showed that the prevalence of deaths in peripheral districts remains and are worsening over time, with less concentration in the central areas.

Figure 4 - Deaths by COVID-19 by district of residence

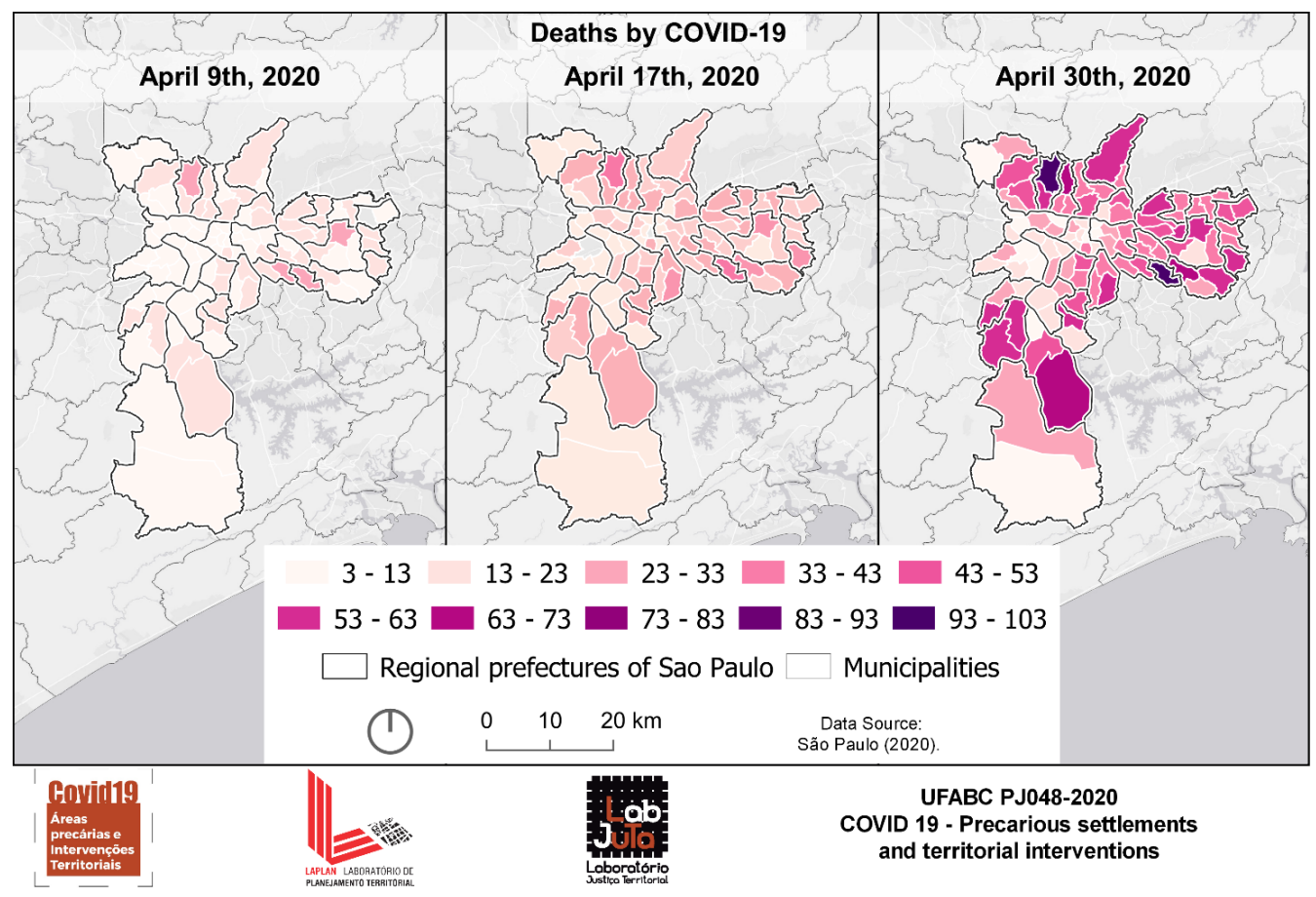

Sources: SIM/PRO-AIM/CEInfo/SMS-SP, 2020.

In addition, the third bulletin, for the first time, brought a qualitative analysis: the racial distribution of deaths (SÃO PAULO, 2020c). The data by race shows differences on deaths, with the incidence of death being $62 \%$ higher in black people and $23 \%$, in 
brown ones, both compared to the white. Despite the bad management of notifications and the uncertainties that result from such data, which require further monitoring, the observation of deaths proves, again, the links with inequalities.

Regarding the cases, the third bulletin contains two different maps: confirmed cases, with SUS and Sivep-Gripe data; and confirmed and suspected cases, with SivepGripe data. In the first map, Morumbi (central-southeast area) is the district with more cases (331), followed by Itaquera (227). The second map presents Sapopemba and Jardim Ângela (307 and 283 cases) with the largest number of cases, followed by Itaquera, Capão Redondo, Jabaquara, Jardim São Luiz, Grajaú, Tiradentes, São Mateus, Brasilândia and Sacomã (with 199 cases) - all of them in periphery areas. The Morumbi district (with 65 cases) is not a highlight on this map. The document points out that the distribution of the second map would be "more reliable for the development of the epidemic in the city, since it portrays precisely the most serious cases, which require hospital care" (SÃO PAULO, 2020c: 13).

It is not easy to understand exactly what these discrepancies represent. Interpretations of death data may suggest different patterns of lethality, however, it is most likely that the difference between the maps is related to the highest and lowest testing - the district with the highest number of confirmed cases is the more tested. The research is still on, such as the pandemic, but the official data and the inequalities approach confirm, each day more, that there is a territorial disadvantage of the COVID-19 spread in São Paulo City.

Until this paper's submission, there is no updated Epidemiological Bulletin that enables to understand the intra-urban distribution or the dynamics of the escalation of new cases. Also, the more disaggregated data remains not available, even though they could be useful to understand what happens in the clusters: slum perimeters and other informal contexts. The evolution reported to date indicates the peripheral districts as those that concentrate the highest number of deaths. It corresponds to the dimensions of inequality presented above and in the survey about the adherence to isolation, where less adherence is perceived in districts in the northern, southern and eastern ends of the city.

\section{Final considerations}

As presented above, the data and discussion demonstrate how the infection by SARS-CoV 2 and the death resulting from COVID-19 overlap with other territorial inequalities in the municipality of São Paulo. Thus, the pandemic can be an opportunity to change the status quo, bringing the fight against inequalities to the center of the debates and the territorial planning and public policy agenda.

The multiple dimensions of inequalities that intersect the lives affected by environmental injustices are essentials to be observed in order to adequate each territorial intervention with existing conflicts. Therefore, critical approaches to ecological crises have responses to conflicts between nature and society. It is opportune to recover the model of urban development, subordinated to environmental justice suggested by Acserald (2001), in which it is necessary to: democratize the territories; fight socio-spatial 
segregation; defend the right to access urban services and equipment, including health equipment; overcoming social inequality; and reduce socio-environmental vulnerability. This article emphasizes that it is necessary to include the priority addressing of public policies for the peripheries, considering the integrated approach of plans, programs and actions, to achieve transformative agendas.

Through the implementation of this agenda, it will be possible to observe less unequal territorial impacts of pandemics, epidemics and, as a thematic expansion, the impacts of environmental degradation and climate change. It remains to understand whether the society's capacity of implementing such measures would not be the same of mitigating and, perhaps, eliminating these risks and impacts, in the construction of new social, economic and nature-society relations.

\section{Acknowledgements}

The authors thanks the following institution for supporting this research: PROECUFABC, process: PJ048-2020; and the São Paulo Research Foundation (FAPESP), process: 2015/03804-9. The authors also wants to thanks Bruna de Souza Fernandes for the thematic maps elaboration through FAPESP process n. 2018/05968-7.

\section{References}

ACSELRAD, H. A duração das cidades: sustentabilidade e risco nas políticas urbanas. Rio de Janeiro: DP\&A Editora, 2001.

AHMED, F. et al. Why inequality could spread COVID-19. The Lancet Public Health, 2020. ISSN 2468-2667. Doi: https://doi.org/10.1016/S2468-2667(20)30085-2.

ARMITAGE, R.; NELLUMS, L. Considering inequalities in the school closure response to COVID-19. The Lancet Global Health, 2020. ISSN 2214-109X. Doi: https://doi.org/10.1016/ S2214-109X(20)30116-9.

BARROS, M. et al. Tendências das desigualdades sociais e demográficas na prevalência de doenças crônicas no Brasil, PNAD: 2003 - 2008. Ciênc. saúde coletiva [online]. 2011, v.16, n.9 pp.37553768. Available from: <http://www.scielo.br/scielo.php?script=sci_arttext\&pid=S1413$-81232011001000012 \& \operatorname{lng}=$ en\&nrm $=$ iso $>$ ISSN1413-8123 > . https://doi.org/10.1590/S1413 . 81232011001000012 .

BAPTISTA, A.; FERNANDES, L. COVID-19, Análise das estratégias de prevenção, cuidados e complicações sintomáticas. DESAFIOS - Revista Interdisciplinar da Universidade Federal do Tocantins, v. 7, n. Especial-3, p. 38-47, 22 abr. 2020.

CONNOLLY, C.; KEIL, R.; ALI, H. Extended urbanisation and the spatialities of infectious disease: Demographic change, infrastructure and governance. Urban Studies, 2020. Doi: https:// doi.org/10.1177/0042098020910873. 
FRANCISCO, P. et al. Prevalência simultânea de hipertensão e diabetes em idosos brasileiros: desigualdades individuais e contextuais. Ciênc. saúde coletiva [online]. 2018, v. 23, n.11, pp.3829-3840. Available from: http://www.scielo.br/scielo.php?script=sci_arttext\&pid=S1413 $-81232018001103829 \& \operatorname{lng}=$ pt\&nrm=iso Access on: May 162020.

HELLER, L.; MOTA, C.; GRECO, D. COVID-19 faecal-oral transmission: Are we asking the right questions?, Science of the Total Environment, 729, Ago/2020, 138919. Available from: https://www.sciencedirect.com/science/article/pii/S0048969720324360?dgcid=author. Access on: May 172020.

MOREIRA, R. et al. Coronavírus, periferias e áreas precárias: relatos de uma experiência de mobilização por meios virtuais. In: Leonel, Ana Lia; Moreno, Robson da Silva; Momm, Sandra. Práticas Insurgentes na Macrometrópole (no prelo), 2020.

NORONHA, K. et al. Pandemia por COVID-19 no Brasil: análise da demanda e da oferta de leitos e equipamentos de ventilação assistida considerando os diferenciais de estrutura etária, perfil etário de infecção, risco etário de internação e distâncias territoriais. Nota Técnica n.1. CEDEPLAR/UFMG: Belo Horizonte, 2020.

SÃO PAULO, Prefeitura do Município de. Secretaria Municipal da Saúde. COVID-19 Boletim Semanal no1. São Paulo, 31 de março de 2020a. Available from: < https://www.prefeitura.sp.gov. $\mathrm{br} /$ cidade/secretarias/upload/saude/COVID19_relatorio_31de_marco.pdf $>$. Access on: May 17 2020.

SÃO PAULO, Prefeitura do Município de. Secretaria Municipal da Saúde. COVID-19 Boletim Semanal n². São Paulo, 17 de abril de 2020b. Available from: < https:/www.prefeitura.sp.gov. br/cidade/secretarias/upload/saude/PMSP_SMS_COVID19_Boletim\%20Semanal_20200417_ atualizado.pdf $>$. Access on: May 172020.

SÃO PAULO, Prefeitura do Município de. Secretaria Municipal da Saúde. COVID-19 Boletim Semanal no3. São Paulo, 30 de abril de 2020c. Available from: <https://www.prefeitura.sp.gov. br/cidade/secretarias/upload/saude/PMSP_SMS_COVID19_Boletim\%20Quinzenal_20200430. pdf>. Access on: May 172020.

SÃO PAULO, Prefeitura do Município de. Secretaria Municipal da Saúde. Boletim diário Covid-19 no município de São Paulo de 9 de maio de 2020. São Paulo, 09 de maio de 2020d. Available from: <https://www.prefeitura.sp.gov.br/cidade/secretarias/upload/saude/09052020boletim _ covid19_diariov2.pdf $>$. Access on: May 182020.

SÃO PAULO, Prefeitura do Município de. Secretaria Municipal da Saúde (SMS); Instituto Via Pública. Atlas da Saúde da Cidade de São Paulo. Secretaria da Saúde; Instituto Via Pública/ São Paulo: Instituto Via Pública, 2012.

SECRETARIA DE SAÚDE DO ESTADO DE SÃO PAULO (SSESP). Situação Epidemiológica, 2020. Available from: <http://www.saude.sp.gov.br/cve-centro-de-vigilancia-epidemiologica- prof.-alexandre-vranjac/areas-de-vigilancia/doencas-de-transmissao-respiratoria/coronavirus-covid-19/situacao-epidemiologica>. Access on: April 192020.

SELEM, S. Padrões da dieta e hipertensão em adultos e idosos de São Paulo. 2012. 105 fls. Dissertação de Mestrado em Nutrição em Saúde Pública, Faculdade de Saúde Pública, Universidade 
de São Paulo, 2012.

STRINGHINI, S. et al. Socioeconomic status and the $25 \times 25$ risk factors as determinants of premature mortality: a multicohort study and meta-analysis of 1.7 million men and women. The Lancet, v. 389, i. 10075, 1229 - 1237, 2017.

TORRES, P., LINKE, C. Covid-19 e a política urbana: a densidade não é a vilã. Le Monde Diplomatique, 2020. Available from: https://diplomatique.org.br/covid-19-e-a-politica-urbana-a-densidade-nao-e-a-vila/ Access on: May 182020.

TRAVASSOS, L. et al. Why do extreme events still kill in the São Paulo Macro Metropolis Region? Chronicle of a death foretold in the global south, International Journal of Urban Sustainable Development, 2020. DOI: 10.1080/19463138.2020.1762197

VILAR, R. Paraisópolis (picture). In: WIKIPÉDIA: a enciclopédia livre. Wikimedia, 2014. Disponível em: < https:/pt.wikipedia.org/wiki/Parais\%C3\%B3polis_(bairro_de_S\%C3\%A3o_Paulo)\#/media/Ficheiro:Parais\%C3\%B3polis_I.jpg >. Access on: May $1820 \overline{20}$.

WOLF, M. Rethinking Urban Epidemiology: Natures, Networks and Materialities. Int J Urban Regional, 40: 958-982, 2016. Doi: 10.1111/1468-2427.12381. 
Luciana R. F. C. Travassos

$\square$ luciana.travassos@ufabc.edu.br

ORCiD: https://orcid.org/0000-0001-8369-8704
Submitted on: 06/06/2020

Accepted on: 11/06/2020

2020;23:e0111

\section{Renata M. P. Moreira}

$\square$ renata.moreira@ufabc.edu.br

ORCiD: https://orcid.org/0000-0002-3953-9340

\section{Rayssa Saidel Cortez}

$\square$ cortezrayssa@gmail.com

ORCiD: https://orcid.org/0000-0002-3096-4391

How to cite: TRAVASSOS, L. R. F. C.; MOREIRA, R. M.P.; CORTEZ, R. S. The virus, the disease and the inequality. Ambiente $\&$ Sociedade. São Paulo, v. 23, p. 1-12, 2020. 


\title{
O VÍRUS, A DOENÇA E A DESIGUALDADE
}

\author{
Luciana R. F. C. Travassos \\ Renata M. P. Moreira \\ Rayssa Saidel Cortez
}

São Paulo. Vol. 23, 2020

Ideias em debate

A época $\mathrm{CO}$. VID-19: Pesquisa interdisciplinar e uma nova ética sustentável e justa
Resumo: Conforme avança, a pandemia COVID-19 expressa múltiplas dimensões territoriais. As análises aqui apresentadas acerca dos dados de casos e óbitos notificados permitem relacionar a evolução da pandemia com desigualdades já presentes no espaço urbano paulistano e com as diferentes condições sociais existentes para se aderir ao isolamento. Este artigo apresenta argumentos que dialogam com a perspectiva da justiça ambiental, discutindo alguns impactos das desigualdades territoriais na vida e morte dos paulistanos, pela distribuição de fatores tais como: características urbanas, trabalho, comorbidades, equipamentos e acesso à saúde, que mantém um padrão centro periferia. Por se tratar da observação de um caso em andamento, trata-se de um trabalho exploratório, com hipóteses abertas.

Palavras-chave: desigualdades; periferia; COVID-19; justiça ambiental; São Paulo - Brasil.

Como citar: TRAVASSOS, L. R. F. C.; MOREIRA, R. M.P.; CORTEZ, R. S. O vírus, a doença e a desigualdade. Ambiente $\mathbb{\&}$ Sociedade. São Paulo, v. 23, p. 1-12, 2020.

DOI: http://dx.doi.org/10.1590/1809-4422asoc20200111vu2020L3ID 


\title{
EL VIRUS, \\ LA ENFERMEDAD Y LA DESIGUALDAD
}

\author{
Luciana R. F. C. Travassos \\ Renata M. P. Moreira \\ Rayssa Saidel Cortez
}

São Paulo. Vol. 23, 2020

Ideas en debate

\section{La época COV.}

ID-19: investigación interdisciplinaria y una nueva ética sostenible y justa
Resumen: En la medida que avanza, la pandemia de COVID-19 expresa múltiples dimensiones territoriales. Los análisis presentados aquí sobre los casos reportados y los datos de muertes permiten relacionar la evolución de la pandemia con las desigualdades preexistentes en el espacio urbano de São Paulo y con las diferentes condiciones sociales al adherirse al aislamiento. Este artículo presenta argumentos que dialogan con la perspectiva de la justicia ambiental, discutiendo algunos impactos de las desigualdades territoriales en la vida y muerte de los paulistanos, por la distribución de factores como: caracteristicas, trabajo, comorbilidades, equipamiento y acceso a la salud, que mantiene un patrón centro-periferia. Como es una observación de un caso en curso, es un estudio exploratorio, con hipótesis abiertas.

Palabras clave: desigualdades; periferia; COVID-19; la justicia ambiental; Sao Paulo - Brasil.

Como citar: TRAVASSOS, L. R. F. C.; MOREIRA, R. M.P.; CORTEZ, R. S. The. El Virus, la enfermedad y la desigualdad. Ambiente $\&$ Sociedade. São Paulo, v. 23, p. 1-12, 2020.

DOI: http://dx.doi.org/10.1590/1809-4422asoc20200111vu2020L3ID 